\title{
Article \\ Influence of the Residents' Perception of Overtourism on the Selection of Innovative Anti-Overtourism Solutions
}

\author{
Michał Żemła ${ }^{1}$ (D) and Adam R. Szromek ${ }^{2, *(D)}$ \\ 1 Department of Tourism and Regional Studies, Pedagogical University of Cracow, 30-084 Cracow, Poland; \\ michalzemla@gazeta.pl \\ 2 Department of Organization and Management, Institute of Economy and Informatics, \\ Silesian University of Technology, 44-100 Gliwice, Poland \\ * Correspondence: szromek@polsl.pl
}

\section{check for}

updates

Citation: Żemła, M.; Szromek, A.R. Influence of the Residents' Perception of Overtourism on the Selection of Innovative Anti-Overtourism Solutions. J. Open Innov. Technol. Mark. Complex. 2021, 7, 202. https:// doi.org/10.3390/joitmc7030202

Received: 9 August 2021

Accepted: 9 September 2021

Published: 10 September 2021

Publisher's Note: MDPI stays neutral with regard to jurisdictional claims in published maps and institutional affiliations.

Copyright: (c) 2021 by the authors. Licensee MDPI, Basel, Switzerland. This article is an open access article distributed under the terms and conditions of the Creative Commons Attribution (CC BY) license (https:// creativecommons.org/licenses/by/ $4.0 /)$.

\begin{abstract}
With a constantly and rapidly increasing number of publications, modern expertise on overtourism is becoming increasingly complete. However, a subject that has not been sufficiently presented in the literature thus far is the issue of identifying groups of inhabitants of various destinations that are most severely affected by overtourism and the perception of innovative remedial solutions. In numerous previous publications that analyzed the impact of overtourism on the inhabitants of destinations, the inhabitants were most often treated as a homogeneous group. Therefore, the main goal of this article is to describe the phenomenon of overtourism from the perspective of residents of two Polish tourist destinations and propose innovative solutions to the problem of tourist overcrowding, dedicated to areas with different specificities. Empirical research was conducted among the inhabitants of popular destinations in Poland-Kraków and Białka Tatrzańska-where overtourism has been noted in the scientific literature in recent years. The results allow us to outline significant differences in how the impact of overtourism is perceived by the inhabitants of a large city and a peripheral tourist resort. Additionally, the research demonstrated that respondents who live in the central part of a tourist destination much more clearly perceive their exposure to the effects of overtourism than the inhabitants of other parts, and that this phenomenon is more evident in cities than in resorts. According to the diagnosis of the situation, it was proposed to implement open innovations in the nature of preventive solutions.
\end{abstract}

Keywords: overtourism; tourism innovation; open innovation; tourism impact; destination residents; city tourism; tourism resort

\section{Introduction}

Overtourism is one of the most popular subjects in contemporary research in tourism. According to the scholar.google search engine, just in the period between the beginning of 2020 and the end of November 2020, 173 publications contained the word "overtourism" in their title. In contrast, in 2017, there were only 37 such publications. Such a surge in the number of published studies on this topic is understandable because what we are dealing with is a relatively new phenomenon. Its scale, causes, and manifestations differ significantly from everything that has been undisputedly examined and documented in scientific knowledge in tourism. The change brought about by the development of overtourism has had such significant consequences for stakeholders' ways of running a business, especially in large cities, that it is sometimes referred to as third-order change [1,2] that involves a shift in the whole tourist policy paradigm, including an adaptation of a new goal hierarchy [3] and innovative solutions [4]. With a constantly and rapidly increasing number of publications, modern expertise about this phenomenon is becoming increasingly complete. Places that are particularly susceptible to the overtourism phenomenon and those where it can be seen are indicated [5-8]. We better understand its causes $[3,9,10]$ and effects [3,10-19], and we are better able to track down the links of overtourism with other 
phenomena related to modern tourism, such as the sharing economy [20-24], the night economy $[25,26]$, gentrification $[9,27,28]$, and low-cost airlines [29]. However, we do not know whether the implemented innovations, including open innovations, should apply to all dimensions and types of tourist areas.

A subject that has not been sufficiently presented in the literature thus far is the issue of identifying groups of inhabitants of various destinations that are most severely affected by overtourism. This article is an attempt to partially fill that gap. Therefore, the main aim of this article is to describe the phenomenon of overtourism using the authors' own methodology of measuring this phenomenon from the perspective of residents of tourist destinations and to identify those factors that make residents more exposed to the impact of overtourism. Consequently, a supplement to the main goal is to indicate whether the implementation of innovations in tourism that counteract overtourism should depend on the analyzed factors.

The adopted measurement methodology covers four non-economic subject areas, which have a direct impact on the perception of overtourism. Due to the breadth of the issue, economic factors will be taken up in further parts of the authors' research. The research areas discussed here include the following topics: (A) the number of tourists, (B) crowds, (C) noise, (D) safety, and (E) the level of development of the city/town. To implement this study, empirical research was necessary, which was carried out in two tourist destinations of different sizes located in Poland in the central part of the European continent.

This article presents the impact of tourism on the residents of the destination cities and of overtourism thus far. Later, the results of our own questionnaire research were presented, which allowed us to identify the features of the inhabitants that make them particularly vulnerable to the effects of overtourism, and consequently we proposed innovative solutions to the problem of overtourism in various tourist areas.

This paper starts with an extended literature review, in which the idea of overtourism and innovative approaches toward this phenomenon are discussed. The next chapter is devoted to the presentation of the research methods used. A comparison between the perception of inhabitants of two Polish major tourism destinations was made on the basis of the responses to the questionnaire distributed between May and July 2020. This part is followed by the presentation of obtained results. Finally, there is a discussion in which some solutions are suggested, and the paper ends with concluding remarks.

\section{Literature Review}

For many years, at the end of the 20th century and at the beginning of the 21st century, the impact of tourism has been commonly analyzed through the lens of three pillars: economic, sociocultural, and environmental. The theory seemed to be established, and research projects focused on its implementation in particular cases [30-33]. Sustainable tourism development was achieved by balancing positive and negative impacts, and economic benefits and environmental threats were usually emphasized [34]. Sustainability issues were addressed mainly in nature-based destinations, and the slightest of sociocultural impacts were studied even less frequently. The perception of tourism as an effective growth engine for local, regional, and national economies was common and even increased after the 2007-2010 global economic crisis [12]. Support for the development of tourism due to its economic effects was present in numerous scientific papers and textbooks [9]. This attitude changed in the second decade of our century together with numerous developments in contemporary economies and societies. Due to demographic and political situations, the scale of global tourist traffic has reached numbers higher than ever. According to international statistics, the number of international tourist arrivals surpassed 1 billion in 2012, and this number is expected to double by 2030 [35]. This trend has been multiplied by the equally fast growth of domestic tourism [10,36]. Obviously, the growing number of people inhabiting the Earth results in the growing demand for tourism. This huge increase in tourist traffic in recent years, accompanied by tourists' inclination to visit 
popular destinations during the same periods, is frequently presented as the main reason for overtourism $[3,10]$. Apart from those quantitative changes, contemporary tourism is also evolving. People take shorter holidays but travel more often [37], while low-cost carriers [38] and sharing economy platforms [39] allow people to reach different destinations, especially cities, at affordable prices. These changes made large cities among the most important global tourism destinations $[3,40]$. However, sustainable management practices developed largely for nature-based destinations and resorts do not reflect the situation in cities. Having been previously underestimated, the negative sociocultural impacts of tourism were being reconsidered. On the other hand, the environmental impact of growing tourist traffic in many fragile and attractive ecosystems exceeded acceptable limits. This tremendous growth of tourist numbers in recent years, tourists' tendency to travel to popular destinations during the same periods, and new features of contemporary tourism are often pointed to as the leading causes of overtourism [10].

The term overtourism appeared to reflect the contemporary changes in how the impact of tourism was perceived mainly in large cities (such as Barcelona, Paris, Amsterdam, and Milan) and smaller cities (such as Dubrovnik, Venice, and Palma de Mallorca). It assumes that, in several places, the development of the tourism industry became so large that its negative effects overwhelmed the positive impact, spurring anti-tourism attitudes among city residents and environmental activists. The sociocultural impact of tourism on residents of destinations is particularly worth mentioning, as it is not only much greater than the well-known effects from previous years, but also on a larger scale. The contemporary development of tourism that occurs mainly in cities has also yielded issues that were nearly absent previously [3,9]. Those issues are frequently described in publications dealing with the sharing economy, but they are not limited to the development of this phenomenon. Numerous scientists $[23,24,39,41]$ agree that the very fast development of sharing economy platforms such as Airbnb seriously impacts urban real estate markets. The core of that impact is connected to a significant growth in the demand for apartments and houses from prospective operators of home-sharing services. This growth is the reason for numerous consequences that appear in different places and on a different scale [3,41,42]. These are mainly shortages in the real estate market and an increase in prices of long-term residential rentals. Moreover, tourism sharing economy platforms blur the traditional boundaries between residential and tourist areas [43]. Offering accommodation services in quarters that have not been popular among tourists has become an attractive opportunity to earn additional income for owners of houses and apartments, and it has lured many guests attracted by Airbnb's slogan "live like a local" [9]. As a consequence, city residents who previously were able to sidestep tourist traffic by keeping away from the historic city centers have difficulties doing this today, as they meet many tourists accommodated in facilities located immediately next door [44]. Additionally, the behavior of home-sharing users is often perceived as improper [40].

As overtourism came into being, it redefined the way the balance between the costs and benefits of tourism development was understood. The most severe examples of the symptoms of overtourism might be found in market destinations that are very successful and where economic benefits should be impressive. However, those benefits are not distributed equally, and the costs are so significant that the benefits play a minor role in how they are perceived by the majority of residents. Finally, the overwhelming impression of "too much" tourism lowers the satisfaction of tourists who try to avoid the most crowded places in destinations. The tension between tourists and residents also has another source. Tourists who previously often traveled to mass resorts used to be treated as customers and precious clients by everyone in their destinations. Tourists pay for their holidays and expect to obtain the perfect product, and they do not want to limit or adjust their behavior to meet local requirements. In contrast, they expect that the local requirements would rather be changed or adjusted for tourists' satisfaction. Finally, tourists are "blamed" by locals for using public space and infrastructure for free, while the residents are responsible 
for maintaining the facilities with the local budget. Goodwin [9] referred to overtourism as a classic case of the Tragedy of the Commons.

Negative perceptions of the effects of overtourism released rapid and violent antitourism movements, mainly in large cities. This attitude started to be labeled in the literature as tourism-phobia [45]. The pace and the scale of the emerging phenomenon made overtourism one of the most prominent subjects of scientific research in tourism. Several conceptual $[8,9,13,46]$ and empirical $[15,40,47-49]$ studies described the nature and genesis of overtourism. However, several questions remain without answers. While overtourism and tourism-phobia are often associated with cities [10,12,50], Peeters et al. [5] also present numerous examples of nature-based destinations and resorts as infected with overtourism. Nevertheless, to date, the differences between the nature of overtourism in different destinations have not been widely analyzed. Additionally, a large proportion of residents of destinations seem to be heterogenous, and it is necessary to discover which parts of the local population are particularly affected by the effects of overtourism and which are particularly resistant to further tourism development.

Due to the relatively short time since there has been a wide perception of overtourism as an important problem brought by tourism development, there are not many solutions being proposed in the scientific literature or implemented in practice. What is more, the radical change in conditions established by the COVID-19 pandemic and restrictions means that it is very difficult to evaluate the efficiency of those solutions that were already implemented. Typical reactions of local authorities of destinations exercising overtourism were connected with implementations of restrictions of different kinds [9]. Especially in places with very high nature value and vulnerability, it was decided to limit the number of daily visitors or even to close the attraction for tourists for some time [51]. This can be illustrated by the spectacular example of the famous beach Maya in Thailand [52].

However, such simple and radical measures are not possible to implement in urban areas, which are the most common examples of overtourism's "victims" [40]. In that case, to manage the number of visitors, cities' authorities imposed limitations on the development of tourism infrastructure. The establishment of new accommodation facilities was temporarily banned in many places in Spain, including in Barcelona [42,53]. In other cities, including Berlin [42] and Paris [53,54], the transformation of residential buildings and flats into short-term tourism rentals was impeded or even banned, which additionally aimed to protect the local real estate market $[42,55]$. Finally, in Venice and Dubrovnik, limits were implemented on the number of cruise ships [19,46,49,50,56].

Other solutions dealing with means of transport are those that are aimed at promoting more eco-friendly ones, including the establishment of zones accessible only for bicycles, electric scooters, electric cars, or where access of tourist coaches is limited $[51,57,58]$. Finally, active police regarding parking places, their availability, and prices can be implemented. However, the problem of overtourism is much more than just the number of tourists. In many places, including Amsterdam [12] or Palma de Mallorca [59], strict local laws were implemented to protect local people from improper tourists' behavior, including high fees for raptures.

Apart from strict regulations, local stakeholders were also trying to make use of soft tools, including educational campaigns directed to both citizens and visitors [60-62], and incentives promoting particular actions. One very tempting effect of such a tourism policy is the more equal distribution of tourism traffic in time and space [46,62-64]. The success of such a campaign may bring visible relief for citizens living in or close to the most crowded districts without the minimization of the economic output of tourism. However, the task is very challenging, and convincing tourists to visit the destination outside the typical tourism season and/or to visit less-visited attractions instead of those being perceived as landmarks is extremely difficult. What is more, the equal tourism distribution strategy cannot be realized purely by public authorities and private tourism entrepreneurs must play an active role in it, for example, when deciding about their pricing policy and the localization of 
their new investments. There are also doubts about the effects of the spatial redistribution of tourism traffic, and many negative results are also mentioned in the literature [3,9].

Extremely dynamic changes experienced by tourism in the last few years and the journey to overtourism are to be replaced by the COVID-19 merry-go-round of restrictions and loosening calls for an innovative approach to this changing reality. According to Hall [2], the whole tourism policy should be re-established as overtourism needs completely new approaches. Uncertainty brought by global pandemics shows even stronger the need for new, innovative thinking and tools. However, so far very few publications have presented overtourism in the context of innovative thinking. Seraphin, Sheeran, and Pilato [19] presented the idea of an "ambidextrous management" approach to the management of tourist destinations. According to these authors, such an innovative management approach implies putting together two opposites. The first is exploitation, which means focusing on existing customers and/or markets and exploiting and improving the existing products, services, competencies, and operating strategies [19]. The second is an exploration that is creative and innovative, with a focus on the future such as experimenting with new products, services, competencies, and operating strategies.

Quite a different approach to innovations in times of overtourism is presented by Perles-Ribes, Ramón-Rodríguez, Moreno-Izquierdo, and Such-Devesa [65]. They search for particular innovative tools that may enhance tourism management and suggest the use of machine learning techniques as a tool for predicting overtourism. Another example of information technology-based innovations suggested for tackling overtourism is the use of destination management companies' websites to mediate social tension [66]. Additionally, the idea of smart cities is often recalled as a destination innovation [67].

Undoubtedly, overtourism, as an acute problem for residents of tourist areas, can also be a catalyst for innovative solutions used in tourism management. As the problem of the excess of tourists is an almost universal phenomenon, especially in the group of the most popular tourist destinations, effective solutions used in one of such places are gaining instant popularity in others. Thus, these solutions become open innovations.

The concept of open innovation initiated by H. Chesbrough [68,69] has been developing for two decades [70-76] and finds many interesting applications, including solving current global problems. One of them concerns, for example, innovations related to counteracting the effects of the COVID-19 pandemic [4,77].

Pichlak [78] points out that the essence of this paradigm is to break the limitations resulting from competition for interaction with the environment in order to supplement the possessed resources of technical knowledge, thus gaining additional opportunities to increase the efficiency of the innovative process. However, the basis of this approach is the dichotomous innovation transfer, i.e., the possibility of acquiring technology outside the organization (from outside to inside) [79] or to offer other organizations their own technologies (from inside to outside) [80]. This concept therefore takes two opposite directions of the transfer of knowledge and technology. Pichlak [78] points out that in the first case, the process of the deliberate inflow of new knowledge refers to five categories of elements:

- Absorption of the knowledge of suppliers, consumers, partners, or competitors, which may take the form of conducting market research (in order to learn about consumer preferences) [81];

- $\quad$ External networking [82];

- Outsourcing in the context of research and development activities [83], and;

- The acquisition of intellectual property rights [84].

However, in the case of the opposite direction of knowledge transfer, such activity usually refers to the commercialization of one's own solutions and technologies or to enabling the initiation of new ventures based on one's own intellectual achievements.

The development of open innovation results in many approaches to this concept and attempts to combine it with complementary concepts, e.g., with the concept of business models [85]. However, in the context of the subject matter, the open transfer of knowledge 
with a positive impact on the natural environment becomes important. The issue of open innovations focused on this issue is taken up by Yun and colleagues [86,87]. In this context, open access to innovations that improve the natural environment also becomes a social value. As excessive tourism is a significant threat to the natural environment, the possibility of using innovative solutions by all destinations endangered by this problem also becomes extremely important.

\section{Materials and Methods}

To implement the goal of this work, empirical research was necessary, which was conducted among the inhabitants of two popular tourist destinations in Poland where overtourism has been noted in the scientific literature of recent years. The first destination was Kraków [20,21,24,48,88], while the second was Białka Tatrzańska [89]. The destinations where the research was conducted were selected to allow us to include the opinions of both residents of a large city (Kraków) and a popular mountain resort that offers extensive winter sports (Białka Tatrzańska). A small distance between the destinations and a similar distance from large groups of potential tourists were additional considerations.

The comparison of two selected destinations presented in the article is a case study that can expand the discussion on overtourism by referring to experiences observed in other destinations. The example of these two places can supplement the knowledge about the behavior of residents in relation to tourists in the area of Central and Eastern Europe, where destinations do not attract as many tourists as well-known destinations in Western Europe and America. Thus, overtourism becomes a unique phenomenon in terms of its frequency and strength of impact.

A research questionnaire containing 50 questions grouped into several basic subject categories was used. Based on the analysis of the latest scientific publications dealing with the issues of overtourism, four subject areas (panels) were selected to describe the potential effects of this phenomenon. These areas are as follows: (A) number of tourists [11,15,88]; (B) crowds [7,90,91]; (C) noise [12,25,88]; (D) safety [9,16,17,25]; and (E) development of the city/town $[9,15,50]$.

In addition, the next nine questions (F1-F9) concerned general issues neither closely related to each other nor to other subject areas. Respondents were also additionally grouped to determine the differences of opinions in individual social groups. Thus, additional variables to group the respondents were:

- Destination (residents of Kraków, residents of Białka Tatrzańska);

- Type of destination area (outskirts, outskirts of a center, destination center);

- Sex (female, male);

- $\quad$ Education (primary, vocational, secondary, higher, postgraduate);

- Duration of residence in the destination (<2 years, 2-3 years, 4-10 years, 11-20 years, and $>20$ years).

The basic part of the research questionnaire comprised questions to evaluate the influence of tourism on the everyday life of city residents and entrepreneurs. The respondents were asked about possible conflict situations related to overtourism. The respondents were also asked about their opinions on specific matters and the studied topics, as well as to state if they find certain views true or false. The variants of answers were ranked by assigning them subsequent positions. The scale of grades used was of a five-grade scale in the integer interval from -2 to 2 , i.e., it was calibrated in point 0 , where values below zero meant disagreement with the opinion formulated, and above zero meant agreement with the opinion presented.

By averaging the results and performing a comparative analysis using nonparametric statistical tests, inference was performed. The results are presented as the arithmetic mean, supplemented by the standard deviation ( $x A v \pm S D)$, and sometimes also as the median value $(\mathrm{Me})$ or percentage $(\%)$.

The research questionnaire was analyzed for reliability using Cronbach's alpha coefficient, which in this case was 0.8916 . With that, we can be convinced that the research tool is 
highly reliable. The research questionnaire was completed by interviewers in direct contact with the residents of Kraków and Białka Tatrzańska. Reliable empirical data directly from the respondents were obtained. The questionnaire was made available to respondents directly (on city streets) and indirectly by publishing a link to the online version of the questionnaire on the Internet on social networks of these cities.

A total of 523 randomly selected respondents took part in the research. With the size of the research sample collected, the assumed credibility threshold of the random sample was achieved. The study assumed a maximum statistical error level of $\pm 5 \%$ and a confidence level of $p=0.95$. With that value, the research team needed to collect information from at least 386 respondents. The research conducted significantly exceeds this threshold; therefore, the error for the sample collected is at most $\pm 4.3 \%$.

The collected data were processed, i.e., a statistical analysis, both one-dimensional (in the form of a descriptive analysis) and two-dimensional (in the form of an analysis of the dependence of pairs of examined characteristics), was performed. In particular cases, the significance level of differences between the obtained mean values was also examined. The $U$ (Mann-Whitney) test was used to compare two groups for variables with a distribution other than normal (Shapiro-Wilk test), while in the case of two samples of dependent variables, the Wilcoxon signed rank test was performed. The significance of differences between the structural indices was tested with the chi-square test. Statistical hypotheses were verified using statistical tests, taking into account significance at the level of $\alpha \leq 0.05$. In some cases, statistical multivariate analyses were performed.

\section{Results}

Questionnaires obtained from 523 respondents, including 70.9\% (371) representatives of Kraków and 29.1\% (152) from Białka Tatrzańska, were taken into consideration during the statistical analysis. There were slightly fewer men (34.6\%) than women (65.4\%) among the respondents. The majority of the respondents were people of middle age, i.e., aged $30-50(45.7 \%)$, and young (34.8\%). Mature people, i.e., aged $50-70$, accounted for $16.6 \%$ of the study population.

Most of the respondents had a degree (67.5\%) and a high school education (24.5\%). The majority of the respondents are permanent residents of the towns analyzed (80.9\%), while the others $(19.1 \%)$ are people who live outside the town, but they are involved in various professional activities in these places.

The researchers collected data in various locations of the surveyed destinations, so information from different places of each destination could be gathered. Thus, 38.4\% of the respondents lived in the center of the analyzed tourist destinations, $45.3 \%$ of the respondents lived close to the center, i.e., in quarters adjacent to the center, and the others $(16.3 \%)$ lived on the outskirts.

As mentioned above, the respondents' opinions were assessed based on a five-point scale containing extreme assessments of agreement with the expressed opinions. Then, these assessments were quantified by reducing them to a rating between -2 and 2 and averaging the obtained scores. A result close to zero $(0.0 \pm 0.05)$ indicates that the respondents did not have an explicit opinion. An average score higher than 0.05 means that the vast majority of respondents indicated agreement with the expressed opinion, while a score lower than -0.05 means that the majority of respondents did not agree with the opinion. The ratings expressing consent or objection to the expressed opinions can be graded using two subsequent intervals, where the rating in the interval $|0.05 \div 1.00|$ indicates moderate agreement or objection, while the rating in the interval $|1.01 \div 2.00|$ means explicit agreement or objection.

\subsection{Number of Tourists ("A" Panel)}

It was found that the majority of respondents moderately agree with the opinion that the number of tourists visiting the surveyed tourist destination is definitely too high $(0.22 \pm 1.33)$. This result is very similar in both analyzed destinations, and there is no 
statistically significant difference $(p=0.688)$. Additionally, gender, education, and length of residence in the destination are not grounds on which to differentiate the respondents opinions. A completely different conclusion could be drawn from the comparison of the assessments indicated from those who lived in different parts of the tourist destinations $(p<0.001)$; people living on the outskirts of these places moderately disagreed with the opinion expressed in this way $(-0.18 \pm 1.17)$, while people living in the center of a destination clearly agreed with this opinion $(0.48 \pm 1.44)$.

However, most respondents disagree with the opinion that the large number of tourists visiting the resort is the cause of their discomfort $(-0.16 \pm 1.47)$; this is an average result, however, taking into account the extremes observed, especially in the case of people living on the outskirts of these resorts who do not agree with this statement $(-0.6 \pm 1.14)$. In contrast, residents of the city centers most often agree with this opinion $(0.31 \pm 1.54)$. This means that the attitude toward tourists and their numbers depends on one's place of residence $(p<0.001)$.

\subsection{Congestion ("B" Panel)}

Taking into account the expressed opinions, the respondents moderately agreed with the opinion that, due to too many tourists and general congestion, they tried to avoid the places most frequently visited by tourists $(0.16 \pm 1.44)$. The residents of the center expressed a clear agreement with this opinion $(0.47 \pm 1.37)$. It is worth noting that people who had lived in a place for less time denied this statement more often, while people who had been residents for medium and long periods more often confirmed that this is the case $(p<0.001)$.

In the case of the view that the large number of tourists in the city causes congestion in public transport, more respondents disagreed with this opinion $(-0.2 \pm 1.22)$.

The respondents agreed that the large number of tourists in the city is the cause of traffic jams and parking problems $(0.38 \pm 1.43)$. However, this result varies between the individual subgroups. A clear agreement with this opinion can be seen in Białka Tatrzańska $(1.57 \pm 0.86)$, while in Kraków, more respondents disagreed with this opinion $(-0.11 \pm 1.32)$. Clear agreement can also be seen among the inhabitants of the destination center $(0.88 \pm 1.33)$. Views on this situation depend on what the education of the respondents is $(p=0.001)$ and on how long they have resided in the city $(p=0.001)$.

In the case of the opinion that the large number of tourists in the city causes traffic jams and parking problems (E3) as well as communication problems, which sometimes irritated the respondent (E5), a significant differentiation of average responses can be seen in various categories of people depending on their length of residence, but no trend can be seen here.

\subsection{Noise ("C" Panel)}

The respondents agree that too many tourists contribute to excessive noise in the city $(0.41 \pm 1.34)$. This problem is more often seen in the destination center than in other places $(0.85 \pm 1.3)$.

The statement that the noise caused by the presence of tourists was sometimes the reason for limiting the quality of their lives was assessed by the respondents in a different way, i.e., most of them do not agree with this statement $(-0.25 \pm 1.47)$. The only subgroup agreeing with this is in the case of the inhabitants of the destination center $(0.39 \pm 1.5)$.

\subsection{Security ("D" Panel)}

In the case of opinions assessing the level of safety, the respondents generally disagreed with the statements provided. The first statement said that the level of safety in their location is lower due to the number and behavior of tourists $(-0.24 \pm 1.35)$. Even greater disagreement was expressed regarding the opinion that the inhabitants do not feel safe in their city because of tourists $(-0.82 \pm 1.32)$. Neither was there agreement with the opinion that, without tourists, the city would be safer $(-0.27 \pm 1.32)$. It should be noted that the 
assessment of these opinions depended on the respondents' education $(p<0.05)$. Clearly, differentiated answers to the questions about safety in the destination were obtained from people in various groups distinguished by the criterion of the period of residence in the location. In this case, however, it is not possible to indicate any linear relationship that would indicate how the perception of security varied as the period of residence increased.

\subsection{Development of Destinations ("E" Panel)}

The opinion about the development of the location was formulated in three statements. The respondents were able to assess compliance with the opinion that thanks to tourist investments (new hotels, new attractions for tourists), the city is prettier. Most of the respondents agreed with this statement $(0.43 \pm 1.31)$. A much more assertive opinion was found among the inhabitants of Białka Tatrzańska $(0.73 \pm 1.35)$ than among the inhabitants of Kraków $(0.31 \pm 1.27)$. Referring to tourism investments and how individuals perceive the quality of life, most of the respondents stated that tourism investments did not translate into a higher quality of living $(-0.31 \pm 1.3)$. However, they agreed that due to investments in tourism, an increasing number of parts of the city had become tourist enclaves rather than residential areas $(0.51 \pm 1.3)$. Additionally, in the case of these two questions, the residents of the resort were much more emphatic, as they noticed the impact of tourism investments on their quality of life $(0.16 \pm 1.37)$ and definitively agreed that the process of creating enclaves only for tourists had taken place $(0.99 \pm 1.19)$. The respondents' opinions on the questions related to the impact of tourism on the development of localities varied depending on the length of residency, but they did not indicate clear relationships.

Taking into account the adopted methodology, a table of average scores for each opinion was obtained (Table 1).

Table 1. Opinions that diagnose the respondents' attitudes to tourists and average rank values.

\begin{tabular}{|c|c|c|c|}
\hline No. & Subject & Opinion & Total \\
\hline A1 & \multirow{2}{*}{$\begin{array}{l}\text { Number of } \\
\text { Tourists }\end{array}$} & The number of tourists visiting the city was far too high & $0.22 \pm 1.33$ \\
\hline A2 & & The large number of tourists visiting the city was a cause of discomfort & $-0.16 \pm 1.47$ \\
\hline B1 & \multirow{5}{*}{ 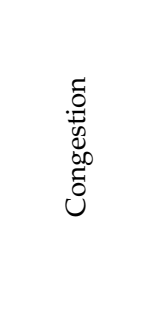 } & $\begin{array}{l}\text { Due to too many tourists and the general congestion in these places, I try to avoid the } \\
\text { places most frequently visited by tourists in my town (e.g., the Old Town in Kraków) }\end{array}$ & $0.16 \pm 1.44$ \\
\hline B2 & & The large number of tourists in the city causes congestion of public transport & $-0.2 \pm 1.22$ \\
\hline B3 & & The large number of tourists in the city causes traffic jams and parking problems & $0.38 \pm 1.43$ \\
\hline B4 & & The lack of tourists let me finally have a rest & $0.08 \pm 1.47$ \\
\hline B5 & & $\begin{array}{l}\text { Communication problems caused by the large number of tourists were sometimes the } \\
\text { cause of my irritation }\end{array}$ & $-0.04 \pm 1.5$ \\
\hline $\mathrm{C} 1$ & \multirow{2}{*}{$\begin{array}{l}0 \\
.0 \\
0 \\
Z\end{array}$} & Too many tourists contribute to excessive noise in the city & $0.41 \pm 1.34$ \\
\hline $\mathrm{C} 2$ & & The noise caused by the presence of tourists sometimes limited my quality of life & $-0.25 \pm 1.47$ \\
\hline D1 & \multirow{3}{*}{ 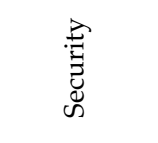 } & The level of security in the town is lower due to tourists, both their number and behavior & $-0.24 \pm 1.35$ \\
\hline D2 & & I did not feel safe in my town because of tourists & $-0.82 \pm 1.32$ \\
\hline D3 & & Without tourists, the town is a safer place & $-0.27 \pm 1.32$ \\
\hline E1 & \multirow{3}{*}{ 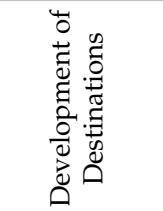 } & Thanks to tourist investments (new hotels, new attractions for tourists), the city is prettier & $0.43 \pm 1.31$ \\
\hline $\mathrm{E} 2$ & & $\begin{array}{l}\text { Thanks to tourist investments (new hotels, new attractions for tourists), my quality of life } \\
\text { is better }\end{array}$ & $-0.31 \pm 1.3$ \\
\hline E3 & & $\begin{array}{l}\text { Due to tourist investments (new hotels, new attractions for tourists), more parts of the city } \\
\text { have become enclaves for tourists, rather than residential areas }\end{array}$ & $0.51 \pm 1.3$ \\
\hline
\end{tabular}


Table 1. Cont.

\begin{tabular}{ccl}
\hline No. & Subject & \multicolumn{1}{c}{ Opinion } \\
\hline F1 & $\begin{array}{l}\text { Foreign tourists are much more irritating than domestic tourists } \\
\text { F2 }\end{array}$ \\
\hline I understand that tourist arrivals are important to our local economy and therefore I am \\
ready to limit my needs (tolerate congestion, noise, lack of privacy)
\end{tabular}

Source: Own study.

\subsection{Results of the Analysis of the Opinions of Tourist Destination Residents (Panel F)}

The respondents were also asked to express their opinion on topics related to their attitude toward the discussed phenomenon. According to the majority of respondents, foreign tourists are not more irritating than domestic tourists $(-0.63 \pm 1.26)$. These opinions are consistent in all subgroups of the study, although in Białka Tatrzańska, this opinion is more pronounced $(0.8 \pm 1.33)$. What is interesting is the lack of significant differences in the respondents' opinions from different parts of the city $(p>0.05)$.

The inhabitants of Białka Tatrzańska express their understanding that tourists' arrivals are important for their local economy and therefore they do not mind limiting their needs (tolerate congestion, noise, lack of privacy) $(0.68 \pm 1.19)$. The inhabitants of Kraków do not express this understanding $(-0.08 \pm 1.27)$.

Most of the respondents stated that they have the impression that the city's and entrepreneurs' actions are focused mainly on amenities for tourists rather than on those of residents $(0.37 \pm 1.31)$. The inhabitants of Białka Tatrzańska $(0.87 \pm 1.18)$ and of the central part of the destination $(0.73 \pm 1.22)$ agree with this opinion more often. The inhabitants of destinations with an average period of residence (4-10 years) are the only group that rejects this view $(-0.21 \pm 1.03)$.

The respondents disagreed with the opinion that due to too many tourists, they do not like spending their free time in the city $(-0.2 \pm 1.42)$. This view was particularly opposed by the inhabitants of Kraków $(-0.29 \pm 1.41)$ and residents of the city outskirts $(-0.51 \pm 1.32)$. The inhabitants of the city center more often agreed with this opinion $(0.17 \pm 1.46)$. Additionally, residents with an average period of residence (4-10 years) are the group that breaks the mold, expressing particularly strong opposition to this opinion $(-0.74 \pm 1.17)$.

The respondents agree that the lack of tourists contributed to the improvement of the natural environment $(0.65 \pm 1.32)$. This was the case in Kraków and in Białka Tatrzańska. It was different from the division by type of area-the closer the respondent lived to the center, the greater the agreement with this viewpoint.

However, the respondents did not agree that they missed seeing tourists (they were not seen there because of the pandemic) $(-0.51 \pm 1.38)$. This phenomenon increases again the closer one lives to the center of the tourist area; on the outskirts, this indicator reached the level of $-0.38 \pm 1.27$, while in the center, it reached $-0.68 \pm 1.4$.

In general, the respondents moderately agreed with the statement that a city without tourists is a more friendly place $(0.16 \pm 1.37)$. However, this result was mainly influenced by Białka Tatrzańska because it was there that greater antagonisms $(0.47 \pm 1.41)$ were noted, while the inhabitants of Kraków $(0.04 \pm 1.34)$ had no opinion. The breakdown by the type 
of city area shows a much greater variability of assessments $(p=0.001)$; the inhabitants of the areas on the outskirts do not think that a city without tourists is more friendly as a place to live $(-0.33 \pm 1.22)$, while the inhabitants of the city center consider it to be the case $(0.49 \pm 1.37)$.

Most of the respondents expressed the hope that once the pandemic ends, tourism in the city would change to a more inhabitant-friendly type of tourism $(0.86 \pm 1.14)$. The inhabitants of Białka Tatrzańska $(1.33 \pm 0.96)$ expressed even greater hopes than the inhabitants of Kraków $(0.67 \pm 1.16)$. Additionally, in this case, there is growing hope for change as the respondent's place of residence moves closer to the destination center. Agreement with the presented thesis also becomes more intense as the period of residence increases.

\subsection{Determining the Importance of Belonging to Different Groups of Inhabitants on How the Effects of Overtourism Are Perceived}

Based on the presented research results, it is difficult to identify one group of inhabitants of a destination who, in particular, bear all the costs related to the development of overtourism in their destination. However, it is clearly visible that the negative consequences of overtourism are much more often experienced by the inhabitants of strict destination centers than by the inhabitants of the outskirts or even districts around the center. In every issue and in almost every question, they perceive the effects of overtourism in significantly different ways than the inhabitants of other districts, and usually, it is a more radical perception of the costs of overtourism. It is also characteristic that the inhabitants of city centers do not perceive any greater benefits from the development of tourism in their lives and surroundings compared to the inhabitants of other districts. Therefore, it is not surprising that they are clearly irritated by the number of tourists where they live (A1, A2).

The inhabitants of the destination centers also observed other negative aspects on the quality of their lives related to the presence of tourists in their immediate vicinity: inappropriate behavior of tourists (A2), noise (C2), and insecurity (D1).

It is worth noting that the inhabitants of other districts do not experience these phenomena in their lives at all. They also express the lowest tendency to understand and limit their own needs for the sake of tourism development (F2). Additionally, only the inhabitants of the centers dislike spending time in their place of living (F4) and disagree with the statement that without tourists, a destination loses its charm (F5). It is worth noting that such marked differences in the opinions of residents of destination centers are mainly in the responses of the residents of Kraków (e.g., F2: Kraków: $-0.08 \pm 1.27$ vs. Białka: $0.68 \pm 1.19$; F4: Kraków: $-0.29 \pm 1.41$ vs. Białka: $0.3 \pm 1.43)$. In contrast, in the case of Białka Tatrzańska, intensive tourism development is seen throughout the village, and the center is even more intense and has greater tourist traffic. Kraków is a city with a clearly separated tourist penetration zone. As is the case of, for example, Prague [92,93], to this day in Kraków, a central district with attractive and valuable historical buildings can be distinguished, where the vast majority of attractions and tourism development facilities are located. It creates a place that can be described as a tourist ghetto [94,95]. Such a significant concentration of tourist traffic in the city center is the reason why the tourist traffic outside the central district is much smaller and the negative impact of tourism is also much smaller, such that tourism is not perceived much by the inhabitants of these areas, who do not often visit the historic center [88,91].

The effects of overtourism are perceived somewhat differently, and this is also reflected in a comparison of the opinions of the inhabitants of a big city (Kraków) and a resort (Białka Tatrzańska). The latter focuses primarily on too many tourists and the consequences related to congestion (B2, B3), noise (C1), or the level of safety (D1). It can clearly be seen that the ways the situation is perceived and assessed in the case of residents of a small destination and in the case of a big city are different. This differentiation may result from the fact that in the case of a small tourist resort, visitors mainly use special facilities designed for them, which has little impact on the inhabitants' living conditions. Moreover, in a resort such as this, the number of tourists per capita and per area unit is much higher than in 
cities [3]. However, in large tourist cities, the impact of Airbnb booking services on the local real estate market is a significant problem, which makes residential premises for residents increasingly expensive and less accessible, as real estate is shifted from the housing market to the more profitable short-term rental market [20,96-99].

It has been noticed that the length of residence does not have a linear impact on how the effects of overtourism are perceived by the inhabitants. However, several elements characteristic of individual segments can be indicated. One is the particular way that overtourism is perceived by residents who have lived for an extended period in a given locality, especially by those who have lived there for over 20 years but also, albeit to a lesser extent, by those who have been living there for 11-20 years. The answers typical for these two groups refer not so much to how the consequences of overtourism are perceived but to the way they described their reaction to too many tourists and to the way tourists behave. People with the longest period of residence in the destination (more than 20 years) are the only group among the respondents who declare that they definitely avoid contact with tourists (B1). On the other hand, people with an 11-20-year period of residence remain undecided on this issue. As a result, neither group of residents unequivocally rejected the statement that they did not like spending time in their location (F4), which was much more definitely denied by the remaining groups of respondents.

On the other hand, it seems that the people who experience the least effects of overtourism are people with an average period of residence (4-10 years). People with this period of residence did not share the opinion with the other groups of respondents that the large number of tourists in the city causes traffic jams and parking problems (B3), that communication problems caused by a large number of tourists sometimes made them irritated (B5), that the level of safety in the location is lower due to tourists, their number, and behavior (D1), and that the city's and entrepreneurs' actions are focused mainly on amenities for tourists rather than on the residents' needs (F3).

Additionally, this group of respondents agreed (as did the group of people with a 2-3-year period of residence) that due to tourist investments, an increasing number of parts of the city are becoming enclaves for tourists rather than for residents, which was relatively weak (E3).

Based on the conducted research, it can be observed that the respondents' answers are relatively little differentiated by typical demographic variables. No statistically significant differences were found between women's and men's responses $(p>0.05)$.

On the other hand, there were some differences between the respondents based on education. People with higher education clearly stood out from the other respondents. What is distinctive is that people in this group most often provided more balanced, less extreme answers than the other respondents (B3, E1, E3, F3).

Significant differences between the answers given by people with higher and secondary education and people with vocational and primary education can also be seen. First, respondents with higher and secondary education, in a fairly moderate manner, affirm the positive effects of tourist arrivals (E3), no such effects (F8), or hope for a better, more friendly development of tourism in the future (F9). In each of these cases, the respondents with vocational and primary education gave much more affirmative answers.

\section{Discussion}

The results from our research allowed us to significantly expand current knowledge about the phenomenon of overtourism by analyzing the scale and nature of the impact of overtourism experienced by various groups of inhabitants of two different destinations that have experienced a rapid increase in the scale of tourist traffic in recent years. This makes it possible to supplement the knowledge of the implementation of innovations counteracting overtourism, which should depend on the analyzed features of tourism destinations. It is also extremely important as the implemented innovations are burdensome for residents. In previous publications that analyzed the impact of overtourism on the inhabitants of destinations $[5,15,56,100,101]$, residents were most often treated as a homoge- 
neous group. The results of the research carried out suggest that this is quite a far-reaching simplification that does not allow us to capture many relevant facts. Without a proper understanding of these differences, it is difficult to fully understand how various groups of inhabitants are involved in anti-tourism movements [19,102,103], their resistance toward further development of tourism $[13,14,47,100]$, or the widely understood phenomenon of tourism-phobia [45,104-106].

First, the results of the conducted research allow us to outline significant differences in how the impact of rapid and excessive tourism development is perceived by the inhabitants of large cities and peripheral tourist resorts. This is a significant contribution to our understanding of whether overtourism is a phenomenon that should be treated as typical only for metropolitan areas $[3,7,10,12,15,50]$ or whether it occurs in many different destinations $[5,6,107]$.

It is interesting that the results support arguments by the adherents of both perspectives. On the one hand, the inhabitants of the tourist resort, i.e., Białka Tatrzańska, observed several negative impacts in their area caused by excessive tourism development, such as congestion, noise, lack of parking spaces, and the feeling of being second-class citizens in their own place of residence. On the other hand, it was in a big city, i.e., Kraków, that the most typical elements of contemporary overtourism were observed, i.e., an aversion toward tourists and further development of tourism. It can certainly be indicated that in the case of cities and resorts, overtourism is a phenomenon that might manifest itself in a different way, and the characteristic feature in distinguishing the perceptions of these inhabitants is that no benefits result from the development of tourism for city residents.

A comparison of how the impact of tourism on the inhabitants of different districts of locations is perceived is a topic that has not been widely discussed in the scientific literature thus far; our research results can shed some light on this matter. The presented research successfully showed that respondents who live in the central part of the destination much more clearly perceive their exposure to the effects of overtourism than the inhabitants of other areas, and this phenomenon can be seen more clearly in a large city than in a tourist resort. The inhabitants of the center, in particular the city center, clearly perceive nearly all the negative effects of overtourism, which is why they definitely do not like their place of residence, where they dislike spending their free time. By strongly emphasizing how the inhabitants of city centers are exposed to the effects of overtourism, this article is part of the stream of extensive research on the development of tourism in city centers, particularly in historical city centers [108-111].

The significant discrepancy between the responses of residents of city centers and other districts is also an important managerial implication. One of the important dilemmas faced by people who manage the development of tourism in cities is the issue of the redistribution of tourist traffic [112], the goal being to distribute it in space more evenly to relieve the most crowded city centers. This strategy finds followers in Prague, Venice, Amsterdam [107], Dubrovnik [46], and Copenhagen [9]. On the other hand, it is strongly criticized by, e.g., Goodwin [9] and Żemła [3], as contributing to negative attitudes toward tourists intensifying in other parts of the city where the negative impact of tourism has not yet been experienced. In the case of cities such as Kraków, Prague, Dubrovnik, or Venice, where the city centers have practically been turned into tourist ghettos [92,113], the dilemma is whether these historic districts should be completely managed by tourism, but thus protect other parts of the city against excessive tourism, or, on the contrary, by relatively evenly distributing tourism throughout space, distributing the negative impact of tourism in many places, but making it non-excessive in any particular place. The responses of Kraków's inhabitants in the analyzed studies show that both solutions are very difficult to achieve and carry the risk of a further uncontrolled increase in tourist traffic and an increase in the negative impact of tourism on the inhabitants.

To date, no studies have been conducted that analyzed how the impact of overtourism on inhabitants was perceived depending on the period of their residence. The presented research results suggest that this may be an important factor that differentiates how the 
impact of tourism is perceived, while mainly residents with the longest period of residence are the group that is worth conducting further detailed research on in the future.

The results of the conducted research on the influence of the level of education on how the impact of overtourism is perceived are also worth noting. To date, numerous studies $[31,32,114,115]$ have most often indicated that the attitude of residents with a higher level of education in tourist destinations is most positive with respect to the development of tourism and tourists. For example, Vareiro et al. [115] indicated that more educated residents had more expectations of the positive impact of tourism and were less worried about the possible negative impacts, while in the present research, although the best educated respondents in many cases expressed more moderate opinions about the negative impact of tourism, they were also more skeptical about its positive impact. It is significant that they assessed the direct impact of tourism on the quality of their lives as particularly low, which may suggest that this group is least professionally involved in tourism and that living in typically residential districts allows them to avoid at least some of the negative effects of overtourism.

Summing up the deliberations above, it is possible to make suggestions on how effective particular innovative solutions towards overtourism might be in the eyes of citizens belonging to different groups (Table 2). Respondents do not complain too much about the number of tourists and limiting their number is not an expected solution. Additionally, this solution is rather not applicable in the cases of a city and of a resort. Other solutions might be effective in particular situations. Limits imposed on the accommodation facilities and road traffic might be effective mainly in the case of centers of big cities. Inhabitants living outside of a city center do not complain about those factors, and in the case of tourist resorts, such a solution may bring more negative economic outcomes than benefits in residents' quality of life. The seasonal redistribution strategy is probably the most welcomed tool by the inhabitants belonging to all groups, but achieving this goal remains a huge challenge. The spatial redistribution of tourism traffic is much more controversial. Benefits exercised in the city centers might be jeopardized by the costs for inhabitants of other districts. However, a different situation might be observed in tourism resorts where spreading tourism traffic to the next quarters is rather warmly welcomed. Another solution that might be accepted by all groups of destination inhabitants is an educational campaign addressed to visitors. However, this will not solve the most important problem, as in their eyes tourists' behavior is rarely pointed to as a reason for lower quality of life. For the same reason, legal restrictions on tourists' behavior can be effective in the eyes of most residents, but can only solve the problem of moderate importance. Residents belonging to almost all groups rather properly estimate not only the costs but also benefits of tourism development, and educating them would not bring positive effects. The creation of a more aware attitude towards tourism among residents with a shorter period of residence in a destination can be an exception here.

Table 2. Potential innovative solutions of overtourism and their usefulness according to particular groups of inhabitants.

\begin{tabular}{|c|c|c|c|c|c|c|}
\hline \multirow{2}{*}{ Innovative Solutions of Overtourism } & \multicolumn{2}{|c|}{ District } & \multicolumn{2}{|c|}{ Type of Destination } & \multicolumn{2}{|c|}{ Period of Inhabitants' Residence } \\
\hline & Centers & Outskirt & City & Resort & Long & Short \\
\hline Limits on road traffic & + & - & + & - & $+/-$ & $+/-$ \\
\hline Limits on number of visitors & - & - & - & - & - & - \\
\hline Limits on number of beds & + & - & + & - & $+/-$ & $+/-$ \\
\hline Spatial redistribution of tourism traffic & + & - & + & + & $+1-$ & $+/-$ \\
\hline Seasonal redistribution of tourism traffic & + & + & + & + & + & + \\
\hline Educational campaigns directed to residents & $+/-$ & $+/-$ & $+/-$ & + & $+/-$ & + \\
\hline Educational campaigns directed to tourists & + & + & + & + & + & + \\
\hline Legal restrictions on tourists' misbehavior & + & - & + & + & + & + \\
\hline
\end{tabular}

Source: Own study. Explanations: "+"—recommendation of using the solution; "-"—recommendation of abandoning the application of the solution. 


\section{Conclusions}

Overtourism has thus far been detected and researched in numerous destinations. These were often single case studies of popular cities such as Barcelona $[8,106,116]$, Budapest [25,47], Munich [15], Dubrovnik [46], Venice [19], and many others. The results of the presented research conducted in two different destinations in Poland complement the studies previously published and expand the knowledge on overtourism by combining the responses of residents of a city and of a resort. We found that residents are not unambiguous either in how the impact of individual elements of the phenomenon of overtourism is perceived or in what they consider their responsibility for facing the problems resulting from tourism. This study identifies the basic features that differentiate the residents' perception of the burden caused by tourism, in particular the place of residence (type of destination) and the location in the center or outside the center of a tourist destination. These differences are generally not in regard to how intense the burdens are but rather how they are perceived.

First, the results of the conducted research require confirmation through analyses conducted in other destinations, in other countries, and in other cultural circles. Compared to many other large-city tourist destinations, Kraków is a relatively specific place mainly because tourist attractions, tourist bases, and tourist traffic are concentrated in a clearly separated historical center $[48,117]$. Although there are examples of other cities with similar features (Prague, Vienna) [92,93], in many other cities, such as Paris or London, tourism is more dispersed over a larger area of the city, and the streams of tourists are more mixed with the streams of residents $[104,118,119]$. This may have a significant impact on the respondents' responses and, in particular, on the opinions of a clearly distinguished group of residents-those of city centers.

The analysis of attitudes of residents of other types of destinations, as well as of destinations from other parts of the world, is also a desired area of future research. This kind of research could supplement the presented results by removing the limitations of the analysis of only two tourist destinations. However, the authors hope that these studies will initiate many other analyses by applying the adopted methodology of the scope and measurement of the overtourism phenomenon.

It should also be kept in mind that the research material was collected during the first wave of the COVID-19 pandemic and just after it. Certainly, the next waves that affected almost all countries of the world, including the vast majority of tourist destinations in the second half of 2020, may have significantly changed the way the lack of tourists was perceived, while the responses collected in the same destinations and from the same respondents in December 2020 may have differed from those collected for this research. However, further development of the pandemic and its impact on tourism remain unknown. It will certainly also define new, future areas of research on the social and cultural impact of tourism and overtourism on destinations' inhabitants. However, the results of this research study carry important hints about the shape of future tourism, namely, residents' attitudes toward tourists returning to popular destinations after the restrictions are raised. It is evident that the inhabitants of Białka Tatrzańska, and probably of many other resorts, anticipate a very strong link between the volume of tourism in their location and their economic conditions. Undoubtedly, they will be hit especially severely by the next pandemic waves and will continue restrictions. In contrast, for most residents of Kraków, tourism is not a factor influencing their income, and prolonging no tourism is perceived as a positive phenomenon. Additionally, some of those who were economically dependent on tourism might be forced to change their profession. That is why the return of a high volume of tourism might not be desired in Kraków or in other popular cities as much as it is in resorts.

Summarizing the discussed issue, the undertaken analysis of the characteristics of various tourist areas indicates the need to adapt solutions limiting the impact of tourist traffic to the specificity of a tourist destination. Tourist innovations of an open nature, thanks to their impact on the natural environment, in addition to their practical value, 
also have a social value. However, their applicability should be made dependent on the specificity of the area, which includes, inter alia, residents' perception of the problem of overtourism.

It is also worth calling for non-economic innovative ways to reduce the effects of overtourism, and the developed practices and solutions should remain open innovations with a social value dimension.

An important limitation of the research discussed here is its narrowing down to four thematic areas relating to non-economic issues. Therefore, the discussed topic should be treated as the first part of the research. The authors' further intention is to also investigate economic issues that influence the perception of the phenomenon of overtourism. These will be factors such as tourist (customer) behavior, prices and availability of goods and services, including housing, economy, and income.

Author Contributions: Conceptualization, M.Ż. and A.R.S.; methodology, M.Ż. and A.R.S.; formal analysis, M.Ż. and A.R.S.; investigation, M.Ż. and A.R.S.; resources, M.Ż.; data curation, A.R.S.; writing—original draft preparation, M.Ż.; writing—review and editing, M.Ż. and A.R.S.; visualization, M.Ż. and A.R.S.; supervision, M.Ż. and A.R.S.; project administration, M.Ż. and A.R.S.; funding acquisition, M.Ż. and A.R.S. Both authors have read and agreed to the published version of the manuscript.

Funding: This paper was published as part of the research project "A business model for health resort enterprises" No. 2017/25/B/HS4/00301, supervised and financed by the National Science Center in Poland and as part of statutory research ROZ 1: 13/010/BK_21/0057 at the Silesian University of Technology, Faculty of Organization and Management, and as part of grant 13/010/RGJ21/0054 from the Rector of the Silesian University of Technology.

Institutional Review Board Statement: Not applicable.

Informed Consent Statement: Not applicable.

Data Availability Statement: Not applicable.

Conflicts of Interest: The authors declare no conflict of interest. The funders had no role in the design of the study; in the collection, analysis, or interpretation of data; in the writing of the manuscript; or in the decision to publish the results.

\section{References}

1. Hall, C.M. Tourism and Politics: Policy, Power and Place; John Wiley \& Sons: Hoboken, NJ, USA, 1994.

2. Hall, C.M. Policy learning and policy failure in sustainable tourism governance: From first-and second-order to third-order change? J. Sustain. Tour. 2011, 19, 649-671. [CrossRef]

3. Żemła, M. Reasons and Consequences of Overtourism in Contemporary Cities-Knowledge Gaps and Future Research. Sustainability 2020, 12, 1729. [CrossRef]

4. Szromek, A.R. The Role of Health Resort Enterprises in Health Prevention during the Epidemic Crisis Caused by COVID-19. J. Open Innov. Technol. Mark. Complex. 2021, 7, 133. [CrossRef]

5. Peeters, P.M.; Gössling, S.; Klijs, J.; Milano, C.; Novelli, M.; Dijkmans, C.H.S.; Mitas, O. Research for TRAN Committee-Overtourism: Impact and Possible Policy Responses; European Parliament, Directorate General for Internal Policies, Policy Department B: Structural and Cohesion Policies, Transport and Tourism: Brussels, Belgium, 2018.

6. Dodds, R.; Butler, R. (Eds.) Overtourism: Issues, Realities and Solutions; Walter de Gruyter GmbH \& Co KG: Cham, Switzerland, 2019; Volume 1.

7. Milano, C. Overtourism and Tourismphobia: Global Trends and Local Contexts; Ostelea School of Tourism \& Hospitality: Barcelona, Spain, 2017.

8. Milano, C. Overtourism, social unrest and tourismphobia. A controversial debate. PASOS Rev. Tur. Patrim. Cult. 2018, 16, 551-564.

9. Goodwin, H. The Challenge of Overtourism. Responsible Tourism Partnership Working Paper 4. 2017. Available online: http: //www.millennium-destinations.com/uploads/4/1/9/7/41979675/rtpwp4overtourism012017.pdf (accessed on 8 September 2021).

10. Phi, G.T. Framing overtourism: A critical news media analysis. Curr. Issues Tour. 2020, 23, 2093-2097. [CrossRef]

11. Novy, J.; Colomb, C. Urban tourism and its discontents. An introduction. In Protest and Resistance in the Tourist City; Colomb, C., Novy, J., Eds.; Routledge: London, UK, 2016; pp. 1-30.

12. Koens, K.; Postma, A.; Papp, B. Is overtourism overused? Understanding the impact of tourism in a city context. Sustainability 2018, 10, 4384. [CrossRef] 
13. Cheer, J.M.; Milano, C.; Novelli, M. Tourism and community resilience in the Anthropocene: Accentuating temporal overtourism. J. Sustain. Tour. 2019, 27, 554-572. [CrossRef]

14. Cheer, J.M.; Milano, C.; Novelli, M. Afterword: Over Overtourism or Just the Beginning? In Overtourism: Excesses, Discontents and Measures in Travel and Tourism; CAB International: Wallingford, UK, 2019; pp. 227-232.

15. Atzori, R. Destination Stakeholders' Perceptions of Overtourism Impacts, Causes, And Responses: The Case of Big Sur, California. J. Destin. Mark. Manag. 2020, 17, 100440. [CrossRef]

16. Seraphin, H. Overtourism: A Merry-Go-Round of Security Issues. In Tourism, Terrorism and Security; Korstanje, M.E., Seraphin, H., Eds.; Emerald Publishing Limited: Bingley, UK, 2020.

17. Seraphin, H.; Gowreesunkar, V.; Zaman, M.; Lorey, T. Limitations of Trexit (tourism exit) as a solution to overtourism. Worldw. Hosp. Tour. Themes 2019, 11, 566-581. [CrossRef]

18. Seraphin, H.; Ivanov, S.; Dosquet, F.; Bourliataux-Lajoinie, S. Archetypes of locals in destinations victim of overtourism. J. Hosp. Tour. Manag. 2020, 43, 283-288. [CrossRef]

19. Seraphin, H.; Sheeran, P.; Pilato, M. Over-tourism and the fall of Venice as a destination. J. Destin. Mark. Manag. 2018, 9, 374-376. [CrossRef]

20. Plichta, G. The problem of short-term rental as a manifestation of the overtourism effect on the housing market in the historical city of Krakow. Świat Nieruchom. 2018, 4, 57-64. [CrossRef]

21. Plichta, J. The co-management and stakeholders theory as a useful approach to manage the problem of overtourism in historical cities-illustrated with an example of Krakow. Int. J. Tour. Cities 2019, 5, 685-699. [CrossRef]

22. Zwolińska-Ligaj, M.; Kacprzak, K. Issues of the Sharing Economy in the Discussion of Overtourism in the Light of the Scopus Database. Studia Perieget. 2019, 4, 119-144.

23. Moreno-Gil, S.; Coca-Stefaniak, J.A. Overtourism and the sharing economy-tourism cities at a crossroads. Int. J. Tour. Cities 2020, 6,1-7. [CrossRef]

24. Zmyślony, P.; Leszczyński, G.; Waligóra, A.; Alejziak, W. The Sharing Economy and Sustainability of Urban Destinations in the (Over) tourism Context: The Social Capital Theory Perspective. Sustainability 2020, 12, 2310. [CrossRef]

25. Pinke-Sziva, I.; Smith, M.; Olt, G.; Berezvai, Z. Overtourism and the night-time economy: A case study of Budapest. Int. J. Tour. Cities 2019, 5, 1-16. [CrossRef]

26. Song, H.; Kim, M.; Park, C. Temporal Distribution as a Solution for Over-Tourism in Night Tourism: The Case of Suwon Hwaseong in South Korea. Sustainability 2020, 12, 2182. [CrossRef]

27. Díaz-Parra, I.; Jover, J. Overtourism, place alienation and the right to the city: Insights from the historic centre of Seville, Spain. J. Sustain. Tour. 2021, 29, 158-175. [CrossRef]

28. Nilsson, J.H. Conceptualizing and contextualizing overtourism: The dynamics of accelerating urban tourism. Int. J. Tour. Cities 2020, 6, 657-671. [CrossRef]

29. Bouchon, F.; Rauscher, M. Cities and tourism, a love and hate story; towards a conceptual framework for urban overtourism management. Int. J. Tour. Cities 2019, 5, 598-619. [CrossRef]

30. Liu, J.C.; Var, T. Resident attitudes toward tourism impacts in Hawaii. Ann. Tour. Res. 1986, 13, 193-214. [CrossRef]

31. Husbands, W. Social status and perception of tourism in Zambia. Ann. Tour. Res. 1989, 16, 237-253. [CrossRef]

32. Haralambopoulos, N.; Pizam, A. Perceived impacts of tourism: The case of Samos. Ann. Tour. Res. 1996, 23, 503-526. [CrossRef]

33. Gilbert, D.; Clark, M. An exploratory examination of urban tourism impact, with reference to residents attitudes, in the cities of Canterbury and Guildford. Cities 1997, 14, 343-352. [CrossRef]

34. Hunter, C. Sustainable tourism as an adaptive paradigm. Ann. Tour. Res. 1997, 24, 850-867. [CrossRef]

35. UNWTO. Overtourism? Understanding and Managing Urban Tourism Growth beyond Perceptions: Executive Summary; UNWTO: Madrid, Spain, 2020.

36. Hall, C.M. On the mobility of tourism mobilities. Curr. Issues Tour. 2015, 18, 7-10. [CrossRef]

37. Losada, N.; Alén, E.; Domínguez, T.; Nicolau, J.L. Travel frequency of seniors tourists. Tour. Manag. 2016, 53, 88-95. [CrossRef]

38. Santos, A.; Cincera, M. Tourism demand, low cost carriers and European institutions: The case of Brussels. J. Transp. Geogr. 2018, 73, 163-171. [CrossRef]

39. Dogru, T.; Mody, M.; Suess, C.; Line, N.; Bonn, M. Airbnb 2.0: Is It a Sharing Economy Platform or A Lodging Corporation? Tour. Manag. 2020, 78, 104049. [CrossRef]

40. Namberger, P.; Jackisch, S.; Schmude, J.; Karl, M. Overcrowding, overtourism and local level disturbance: How much can Munich handle? Tour. Plan. Dev. 2019, 16, 452-472. [CrossRef]

41. Horn, K.; Merante, M. Is home sharing driving up rents? Evidence from Airbnb in Boston. J. Hous. Econ. 2017, 38, 14-24. [CrossRef]

42. Dredge, D.; Gyimóthy, S.; Birkbak, A.; Elgaard Jensen, T.; Madsen, A. The Impact of Regulatory Approaches Targeting Collaborative Economy in the Tourism Accommodation Sector: Barcelona, Berlin, Amsterdam and Paris. Impulse Paper. 2016. Available online: https:/ / papers.ssrn.com/sol3/papers.cfm?abstract_id=2853564 (accessed on 8 September 2021).

43. Gurran, N.; Phibbs, P. When tourists move in: How should urban planners respond to Airbnb? J. Am. Plan. Assoc. 2017, 83, 80-92. [CrossRef]

44. Ključnikov, A.; Krajčík, V.; Vincúrová, Z. International sharing economy: The case of Airbnb in the Czech Republic. Econ. Sociol. 2018, 11, 126-137. [CrossRef] 
45. Milano, C.; Novelli, M.; Cheer, J.M. Overtourism and tourismphobia: A journey through four decades of tourism development, planning and local concerns. Tour. Plan. Dev. 2019, 16, 353-357.

46. Panayiotopoulos, A.; Pisano, C. Overtourism dystopias and socialist utopias: Towards an urban armature for Dubrovnik. Tour. Plan. Dev. 2019, 16, 393-410. [CrossRef]

47. Smith, M.K.; Pinke-Sziva, I.; Olt, G. Overtourism and resident resistance in Budapest. Tour. Plan. Dev. 2019, 16, 376-392. [CrossRef]

48. Szromek, A.R.; Kruczek, Z.; Walas, B. The Attitude of Tourist Destination Residents towards the Effects of Overtourism-Kraków Case Study. Sustainability 2020, 12, 228. [CrossRef]

49. Gonzalez, V.M.; Coromina, L.; Galí, N. Overtourism: Residents' perceptions of tourism impact as an indicator of resident social carrying capacity-case study of a Spanish heritage town. Tour. Rev. 2018, 73, 277-296. [CrossRef]

50. Capocchi, A.; Vallone, C.; Pierotti, M.; Amaduzzi, A. Overtourism: A literature review to assess implications and future perspectives. Sustainability 2019, 11, 3303. [CrossRef]

51. Scuttari, A.; Isetti, G.; Habicher, D. Visitor management in world heritage sites: Does overtourism-driven traffic management affect tourist targets, behaviour and satisfaction? In Overtourism: Tourism Management and Solutions; Pechlaner, H., Innerhofer, E., Erschbamer, G., Eds.; Routledge: Abingdon, UK, 2019.

52. Hess, J. Thailand: Shutting down a destination. In Overtourism: Issues, Realities and Solutions; Dodds, R., Butler, R., Eds.; Degruyter: Berlin, Germany; Boston, MA, USA, 2019; pp. 111-124.

53. Żemła, M.; Jaremen, D.; Nawrocka, E. Consequences of development of the sharing economy in tourism for cities-theory and examples. Stud. Ind. Geogr. Comm. Pol. Geogr. Soc. 2021, 35, 109-122.

54. Wong, T.C.; Goldblum, C. Social housing in France. A permanent and multifaceted challenge for public policies. Land Use Policy 2016, 54, 95-102. [CrossRef]

55. Jaremen, D.E.; Nawrocka, E.; Żemła, M. Externalities of development of the sharing economy in tourism cities. Int. J. Tour. Cities 2020, 6, 138-157. [CrossRef]

56. González, A.T. Venice: The problem of overtourism and the impact of cruises. Investig. Reg. J. Reg. Res. 2018, 42, 35-51.

57. Kim, S.; Kim, N. A social cost-benefit analysis of the vehicle restriction policy for reducing overtourism in Udo, Korea. Sustainability 2020, 12, 612. [CrossRef]

58. Weber, F.; Eggli, F.; Ohnmacht, T.; Stettler, J. 12. Lucerne and the impact of Asian group tours. In Overtourism; De Gruyter Oldenbourg: Munich, Germany, 2019; pp. 169-184.

59. San Tropez, M.G. ABC of Overtourism Education. In Overtourism; Palgrave Macmillan: Cham, Switzerland, 2020 ; pp. $287-318$.

60. Korstanje, M.; George, B. Demarketing overtourism: The role of educational interventions. In Overtourism and Tourism Education; Routledge: Oxford, UK, 2020; pp. 81-95.

61. Carreira, V.; Azeredo, J.; González-Rodríguez, M.R.; Díaz-Fernández, M.C. The Role of Tourism Education in Overtourism and Destination Management. In Overtourism as Destination Risk; Emerald Publishing Limited: Bingley, UK, 2021.

62. Séraphin, H.; Yallop, A.C. (Eds.) Overtourism and Tourism Education: A Strategy for Sustainable Tourism Futures; Routledge: Oxford, UK, 2020.

63. Sibrijns, G.R.; Vanneste, D. Managing overtourism in collaboration: The case of 'From Capital City to Court City', a tourism redistribution policy project between Amsterdam and The Hague. J. Destin. Mark. Manag. 2021, 20, 100569.

64. Pásková, M.; Wall, G.; Zejda, D.; Zelenka, J. Tourism Carrying Capacity Reconceptualization: Modelling and Management of Destinations. J. Destin. Mark. Manag. 2021, 21, 100638.

65. Perles-Ribes, J.F.; Ramón-Rodríguez, A.; Moreno-Izquierdo, L.; Such-Devesa, M. Competitiveness and overtourism: A proposal for an early warning system in Spanish urban destinations. Eur. J. Tour. Res. 2020, 27, 1-27.

66. Zaman, M.; Thanh, T.V.; Botti, L. Tackling Overtourism and Related Perverse Impacts Using DMO Website as a Tool of Social Innovation. In Overtourism; Palgrave Macmillan: Cham, Switzerland, 2020; pp. 131-147.

67. Pasquinelli, C.; Trunfio, M. Reframing urban overtourism through the Smart-City Lens. Cities 2020, 102, 102729. [CrossRef]

68. Chesbrough, H. Open Innovation: The New Imperative for Creating and Profiting from Technology; Harvard Business School Press: Boston, MA, USA, 2003.

69. Chesbrough, H.W. Business model innovation: It's not just about technology anymore. Strategy Leadersh. 2007, 35, 12-17. [CrossRef]

70. Aziz, E.; Mustapha, H.; Jamila, E.A. A bibliometric study of the recent advances in open innovation concept. Procedia Comput. Sci. 2020, 175, 683-688. [CrossRef]

71. Banu, G.S.; Dumitrescu, A.; Purcărea, A.A.; Isărescu, S.W. Defining Open Innovation Concept Using Business Process Modeling. Procedia Technol. 2016, 22, 1020-1027. [CrossRef]

72. Tang, T.Y.; Fisher, G.J.; Qualls, W.J. The effects of inbound open innovation, outbound open innovation, and team role diversity on open source software project performance. Ind. Mark. Manag. 2021, 94, 216-228. [CrossRef]

73. Moradi, E.; Jafari, S.M.; Doorbash, Z.M.; Mirzaei, A. Impact of organizational inertia on business model innovation, open innovation and corporate performance. Asia Pac. Manag. Rev. 2021, in press. [CrossRef]

74. Dahlander, L.; Gann, D.M.; Wallin, M.W. How open is innovation? A retrospective and ideas forward. Res. Policy 2021, 50, 104218. [CrossRef] 
75. Barbic, F.; Jolink, A.; Niesten, E.; Hidalgo, A. Opening and Closing Open Innovation Projects: A Contractual Perspective. Ind. Mark. Manag. 2021, 94, 174-186. [CrossRef]

76. Neves, A.R.; Costa, J.; Reis, J. Using a Systematic Literature Review to Build a Framework for University-Industry Linkages using Open Innovation. Procedia Comput. Sci. 2021, 181, 23-33. [CrossRef]

77. Chesbrough, H. To recover faster from COVID-19, open up: Managerial implications from an open innovation perspective. Ind. Mark. Manag. 2020, 88, 410-413. [CrossRef]

78. Pichlak, M. Otwarte innowacje jako nowy paradygmat w zarządzaniu innowacjami. Zesz. Nauk. Politech. Ślaskiej-Organ. I Zarzadzanie 2012, 60, 281-294.

79. Burg, E.; Raaij, E.; Berends, H. Dynamics of Open Innovation: A Process Study of the Development of Fiber Metal Laminates. In Proceedings of the American Academy of Management Conference, San Antonio, TX, USA, 12-16 August 2011.

80. Lichtenthaler, U. Open Innovation: Past Research, Current Debates, and Future Directions. In Proceedings of the Academy of Management Perspectives, San Antonio, TX, USA, 12-16 August 2011; Volume 25.

81. Helfat, C.E.; Raubitschek, R.S. Product sequencing co-evolution of knowledge, capabilities and products. Strateg. Manag. J. 2000, 21, 961-979. [CrossRef]

82. Wilhelm, M.; Lerch, F. How Open are Innovation Networks? In Proceedings of the American Academy of Management Conference, San Antonio, TX, USA, 12-16 August 2011; pp. 4-6.

83. Wadhwa, A.; Freitas, I.B.; Sarkar, M. The Paradox of being Open: External Technology Sourcing and Knowledge Protection. In Proceedings of the American Academy of Management Conference, San Antonio, TX, USA, 12-16 August 2011; pp. 11-13.

84. Beamish, P.W.; Lupton, N.C. Managing Joint Ventures. Acad. Manag. Perspect. 2009, 23, 75-94. [CrossRef]

85. Yun, J.J. Business Model Design Compass. In Open Innovation Funnel to Schumpeterian New Combination Business Model Developing Circle; Management for Professionals; Springer: Berlin/Heidelberg, Germany, 2017; pp. 1-248.

86. Yun, J.J.; Zhao, X. Business model innovation through a rectangular compass: From the perspective of open innovation with mechanism design. J. Open Innov. Technol. Mark. Complex. 2020, 6, 131. [CrossRef]

87. Yun, J.J.; Zhao, X.; Wu, J.; Yi, J.C.; Park, K.; Jung, W. Business model, open innovation, and sustainability in car sharing industry-Comparing three economies. Sustainability 2020, 12, 1883. [CrossRef]

88. Kruczek, Z.; Szromek, A.R. The Identification of Values in Business Models of Tourism Enterprises in the Context of the Phenomenon of Overtourism. Sustainability 2020, 12, 1457. [CrossRef]

89. Żemła, M.; Szromek, A. Development models of ski resorts. Selected examples from Poland. In Proceedings of the 5th International Multidisciplinary Scientific Conference on Social Sciences and Arts SGEM 2018, Vienna, Austria, 19-21 March 2018; pp. $145-152$.

90. Perkumienè, D.; Pranskūnienè, R. Overtourism: Between the right to travel and residents' rights. Sustainability 2019, 11, 2138. [CrossRef]

91. Szromek, A.R.; Hysa, B.; Karasek, A. The perception of overtourism from the perspective of different generations. Sustainability 2019, 11, 7151. [CrossRef]

92. Dumbrovská, V.; Fialová, D. Tourist intensity in capital cities in Central Europe: Comparative analysis of tourism in Prague, Vienna and Budapest. Czech J. Tour. 2014, 3, 5-26. [CrossRef]

93. Pixová, M.; Sládek, J. Touristification and awakening civil society in post-socialist Prague. In Protest and Resistance in the Tourist City; Colomb, C., Novy, J., Eds.; Routledge: London, UK, 2017; pp. 73-89.

94. Vaníček, J. Disparities in Urban Tourism in the Czech Republic. Czech J. Tour. 2019, 8, 33-47. [CrossRef]

95. Volo, S. Overtourism: Definitions, Enablers, Impacts and Managerial Challenges. In Overtourism; Séraphin, H., Gladkikh, T., Vo Thanh, T., Eds.; Palgrave Macmillan: Cham, Switzerland, 2020; pp. 11-26.

96. Boros, L.; Dudás, G.; Kovalcsik, T.; Papp, S.; Vida, G. Airbnb in Budapest: Analysing spatial patterns and room of hotels and peer-to-peer accomodations. GeoJ. Tour. Geosites 2018, 10, 26-38.

97. Wegmann, J.; Jiao, J. Taming Airbnb: Toward guiding principles for local regulation of urban vacation rentals based on empirical results from five US cities. Land Use Policy 2017, 69, 494-501. [CrossRef]

98. DiNatale, S.; Lewis, R.; Parker, R. Short-term rentals in small cities in Oregon: Impacts and regulations. Land Use Policy 2018, 79, 407-423. [CrossRef]

99. González-Pérez, J.M. The dispute over tourist cities. Tourism gentrification in the historic Centre of Palma (Majorca, Spain). Tour. Geogr. 2020, 22, 171-191. [CrossRef]

100. Cheung, K.S.; Li, L.H. Understanding visitor-resident relations in overtourism: Developing resilience for sustainable tourism. J. Sustain. Tour. 2019, 27, 1197-1216. [CrossRef]

101. Kuščer, K.; Mihalič, T. Residents' attitudes towards overtourism from the perspective of tourism impacts and cooperation-The case of Ljubljana. Sustainability 2019, 11, 1823. [CrossRef]

102. Genç, V.; Duman, F. Relationship between Overtourism and City Residents; Recent Evaluations on Humanities and Social Sciences; IJOPEC Publication: London, UK, 2019; Volume 195.

103. Milano, C.; Novelli, M.; Cheer, J.M. Overtourism and degrowth: A social movements perspective. J. Sustain. Tour. 2019, 27, 1857-1875. [CrossRef]

104. Martins, M. Tourism planning and tourismphobia: An analysis of the strategic tourism plan of Barcelona 2010-2015. J. Tour. Herit. Serv. Mark. 2018, 4, 3-7. 
105. Milano, C.; Cheer, J.M.; Novelli, M. (Eds.) Overtourism: Excesses, Discontents and Measures in Travel and Tourism; CABI: Wallingford, UK, 2019.

106. Ramos, S.P.; Mundet, L. Tourism-phobia in Barcelona: Dismantling discursive strategies and power games in the construction of a sustainable tourist city. J. Tour. Cult. Chang. 2020, 19, 113-131. [CrossRef]

107. Stanchev, R. The Most Affected European Destinations by Over-Tourism; Universitat de les Illes Beleares: Palma de Mallorca, Spain, 2018.

108. Law, C.M. Regenerating the city centre through leisure and tourism. Built Environ. 2000, 26, 117-129.

109. Dumbrovská, V. Urban tourism development in Prague: From tourist mecca to tourist ghetto. In Tourism in the City; Springer: Cham, Switzerland, 2017; pp. 275-283.

110. García-Hernández, M.; La Calle-Vaquero, D.; Yubero, C. Cultural heritage and urban tourism: Historic city centres under pressure. Sustainability 2017, 9, 1346. [CrossRef]

111. Gusman, I.; Chamusca, P.; Fernandes, J.; Pinto, J. Culture and Tourism in Porto City Centre: Conflicts and (Im) Possible Solutions. Sustainability 2019, 11, 5701. [CrossRef]

112. Camatti, N.; Bertocchi, D.; Carić, H.; van der Borg, J. A digital response system to mitigate overtourism. The case of Dubrovnik. J. Travel Tour. Mark. 2020, 37, 887-901. [CrossRef]

113. Zmyślony, P.; Kowalczyk-Anioł, J. Urban tourism hypertrophy: Who should deal with it? The case of Krakow (Poland). Int. J. Tour. Cities 2019, 5, 247-269. [CrossRef]

114. Teye, V.; Sirakaya, E.; Sönmez, S.F. Residents' attitudes toward tourism development. Ann. Tour. Res. 2002, 29, 668-688. [CrossRef]

115. Vareiro, L.M.D.C.; Remoaldo, P.C.; Cadima Ribeiro, J.A. Residents' perceptions of tourism impacts in Guimarães (Portugal): A cluster analysis. Curr. Issues Tour. 2013, 16, 535-551. [CrossRef]

116. Alonso-Almeida, M.D.M.; Borrajo-Millán, F.; Yi, L. Are social media data pushing overtourism? The case of Barcelona and Chinese tourists. Sustainability 2019, 11, 3356. [CrossRef]

117. Zmyślony, P.; Kowalczyk-Anioł, J.; Dembińska, M. Deconstructing the overtourism-related social conflicts. Sustainability 2020, 12, 1695. [CrossRef]

118. Maitland, R.; Newman, P. Developing metropolitan tourism on the fringe of Central London. Int. J. Tour. Res. 2004, 6, 339-348. [CrossRef]

119. Gutiérrez, J.; García-Palomares, J.C.; Romanillos, G.; Salas-Olmedo, M.H. The eruption of Airbnb in tourist cities: Comparing spatial patterns of hotels and peer-to-peer accommodation in Barcelona. Tour. Manag. 2017, 62, 278-291. [CrossRef] 